\title{
REFORMASI KEBUDAYAAN MASYARAKAT JEPANG
}

\author{
Sri Sudarsih \\ Fakultas Ilmu Budaya Universitas Diponegoro Semarang \\ Email: srisudarsih2005@yahoo.com
}

\begin{abstract}
(Title: Culture Reform of Japanese Society). The nation of Japan have experienced a slump since its defeat in World War II. The State of the community are truly of concern. The nation of Japan immediately first settled in many ways especially the cultural reform. The method used is a description and the interpretation.

The success of the nation of Japan to build his country with cultural reforms. They change the mental attitude through the reform of customs that are no longer in accordance with the changing times. Consistency and continuity into the keyword success of the Nation of Japan. The process of reform for hundreds of years was able to change the character of the nation of Japan to reach its zenith.
\end{abstract}

Keywords: reformation; culture; character

\section{PENDAHULUAN}

Di antara bangsa-bangsa di dunia, Jepang dapat dipandang paling berhasil membawa perubahan menuju masyarakat modern dan sejahtera. Perubahan itu dimulai dari hal-hal yang sifatnya mendasar dalam kehidupan masyarakat, yaitu perubahan dalam pola hidup keseharian. Masyarakat Jepang melakukan perubahan secara menyeluruh dari seluruh lini kehidupun secara bertahap. Masalah kehidupan beragama, bermasyarakat, bernegara diurai dicarikan jalan keluar menuju pada kejayaan bangsa.

Bangsa Jepang selalu melakukan refleksi diri mengenai kekurangan dan ketertinggalannya dari bangsa lain, kemudian merumuskan persoalanpersoalan tersebut. Mengacu pada rumusan masalah kemudian dilakukan langkahlangkah konkret sebagai bentuk penyelesainnya. Persoalan-persoalan yang muncul dalam masyarakat dihadapi dan diselesaikan secara bersama-sama secara konsekuen dan konsisten dalam waktu yang panjang.
Konsekuensi dan konsistensi menjadi kunci keberhasilan dalam membawa perubahan kebiasaan kemudian dapat membentuk karakter bangsa. Akhirnya membawa perubahan besar yaitu revolusi kebudayaan. Bagaimana hal ini dapat dilakukan Bangsa Jepang tentu bukan hal yang mudah. Penting kiranya bangsa lain dapat untuk belajar dari Bangsa Jepang.

\section{METODE}

Metode yang digunakan adalah deskripsi dan interpretasi.

\section{HASIL DAN PEMBAHASAN}

\section{A. Pengertian Reformasi Kebudayaan}

Reformasi adalah perubahan secara drastis untuk perbaikan di suatu masyarakat atau negara (Sugono, 2008: 1154). Sedangkan budaya adalah pikiran; akal budi. Kebudayaan adalah hasil kegiatan dan penciptaan batin (akal budi) manusia seperti kepercayaan, kesenian, dan adat istiadat (http://kbbi.co.id/arti-kata/budaya).

Berdasarkan pada pengertian tersebut maka reformasi kebudayaan adalah penataan kembali terhadap kebudayaanng dirasakan 
tidak lagi membawa harkat dan martabat manusia yang lebih baik. Kebudayaan dilakukan akal budi secara sadar. Sesuatu yang dilakukan manusia tanpa sadar bukan termasuk kebudayaan.

Sebagian besar masyarakat masih berpendapat bahwa kebudayaan meliputi segala manifestasi kehidupan manusia yang berbudi luhur dan bersifat rohani. Arti kebudayaan saat ini telah berkembang, Kebudayaan diartikan sebagai manifestasi kehidupan setiap orang maupun kelompok. Cara-cara hidup manusia dalam menghadapi lingkungan dan, persoalanpersoalan juga termsuk dalam kategori kebudayaan. Kebudayaan tidak hanya diartikan hanya sebatas pada kata benda saja, melainkan sebagai kata kerja (Peursen, 1976: 10-11).

Pergeseran pengertian kebudayaan akan memperluas cakupan pengertian kebudayaan. Pada awalnya pengertian kebudayaan sebatas pada hasil-hasil karya akal budi seperti adat-istiadat, alat-alat, maupun karya seni. Arti kebudayaan meluas termasuk cara berpikir, menghayati kehidupan, menghadapi alam semesta pun tercakup dalam pengertian kebudayaan.

"Satu setengah abad yang lalu filsof Jerman Imanuel Kant sudah menulis bahwa ciri khas kebudayaan adalah terdapat kemampuan manusia untuk mengajar dirinya sendiri. Kebudayaan merupakan sekolah dimana manusia dapat belajar. Dalam kebudayaan manusia tidak hanya bertanya bagaimana sifatsifat sesuatu, melainkan pula bagaimana sesuatu itu seharusnya bersifat"( Peursen, 1976: 14 ).

Artinya dalam proses belajar manusia, sudah seharusnya mengambil jarak terhadap lingkungannya. kemudian memaknai apa yang seharusnya, tidak sekedar memaparkan fakta-fakta saja. Bagaimana manusia mensikapi dan memaknai lingkungannya, inilah kebudayaan.
Kebudayaan berkaitan dengan peradaban. Peradaban memungkinkan manusia mendapatkan gerak hominisasi, contohnya berkat temuan sains dan teknologi bidang kesehatan memungkinkan meningkatkan usia harapan hidup. Sedangkan dengan kebudayaan manusia melangsungkan proses humanisasi, yakni mengungkapkan kemanusiaan manusia supaya kehidupannya bernilai (Sutrisno, 1994:40).

Peursen (1976:180) memetakan kebudayaan dalam tiga tahap yaitu tahap mitis, tahap ontologis dan tahap fungsional. Pengertian ketiga tahap tersebut adalah tahap mitis adalah sikap manusia yang merasakan dirinya dibatasi oleh kekuaan gaib disekitarnya. Manusia menjadi bagian di dalamnya sehingga tidak dapat berdiri sendiri sebagai subjek yang menentukan lingkungan sekitarnya. Manusia tunduk dalam proses mengalirnya alam semesta. Misalnya terjadinya bencana dipahami sebagai bentuk kemarahan para dewa.

Sedangkan tahap kedua adalah ontologis, sikap manuisa yang tidak merasa terkepung lagi oleh kekuatan-kekuatan mitis alam sekitarnya, melainkan sudah bebas dan berani menarik diri sebagai subjek.Manusia mulai mempertanyakan alam sekitarnya dan meneliti. Manusia mulai menyusun teori-teori tentang alam semesta. Sikap manusia semacam ini mulai terlihat bahwa dia sudah berpikir secara rasional. Jawaban-jawaban yang bersifat mitis dibongkar kemudian diteliti dan dicari jawaban yang rasional sehingga muncul ilmu pengetahuan.

Tahap ketiga adalah tahap fungsioanal. Tahap fungsional adalah sikap manusia yang mulai nampak pada manuisa modern. Pada tahap ini manusia selalu mencari keterkaitan, relasi-relasi baru dengan lingkungannya. Segala sesuatu dipandang pada fungsinya saja. Keberadaan alam dan lingkungan senantiasa dikaitkan pada fungsi semata. Keberadaan sesama juga senantiasa dikaitkan dengan fungsinya. 
Pengertian ketiga tahap tersebut tidak berurutan, melainkan tahap yang satu mengandung tahap lainnya. Ketiganya saling berkaitan, yang satu tidak lebih tinggi dari yang lainnya. Sebagai contoh manusia modernpun masih merasa ada kekuatan gaib yang mengatasi dirinya, sekalipun manusia berhasil membongkar jawaban mitis diganti jawaban hasil penelitian rasionalnya. Tahapan-tahapan tersebut hanya bentuk pemetaan alam pikiran dan sikap manusia terhadap lingkungannya sebagai pencipta kebudayaan. Pemetaan itu dalam rangka memahami perkembangan kebudayaan.

\section{B. Membangun Karakter Manusia Jepang}

Keberhasilan Jepang membangun negaranya dengan cara yang mendasar yaitu melakukan reformasi kebudayaan. Mereka merubah sikap mental melalui reformasi adat-istiadat yang tidak lagi cocok dengan perkembangan jaman. Kesadaran untuk mereformasi ini muncul dari golongan kritis masyarakat kelas atas. Pada tahun 1889 sejumlah tokoh masyarakat mengambil inisiatif mendirikan sebuah orgnisasi perubahan yaitu Assosiasi Perubahan Pola Hidup Jepang (Ong, 2017: 15). Mereka adalah golongan orang-orang yang mengagumi budaya barat tentang sopan santun dan disiplin dalam menghargai waktu. Asosiasi ini muncul sebagai antitesa dari sikap masyarakat luas yang meniru gaya hidup bangsa barat, tetapi tidak meniru esensi dari budaya barat yang disiplin dan penuh tata karma. Mereka meniru sisi luarnya. Hasil refleksi atas realitas sosial yang pada akhirnya menimbulkan kesadaran kolektif bahwa Jepang masih tertinggal dibandingkan negara barat. Salah satu tokoh terkemuka Bangsa Jepang adalah Dohi Masataka (Ong, 2017: 24) membuat slogan "heaven helps those who help themselves" (Tuhan akan menolong orangorang yang mau berusaha). Artinya jika ingin maju maka manusia harus berusaha dan bekerja keras, kalau tidak maka Tuhan tidak akan menolong.
Dohi Masataka seperti yang dikutip Ong (2017:25-29) menyusun buku dan menyampaikan kritik-kritik sosial dan mengajak untuk merenungkan apakah ajaran agama, ajaran moral dan sanksi hukum bisa membawa perubahan? Dohi Masataka berkesimpulan bahwa semua itu tidak cukup membawa perubahan untuk kemajuan Jepang dalam mengejar ketertinggalan. Kenapa demikian? Pertama, pemuka agama Buddha yang seharusnya paling efektif mengajak melakukan perubahan ke arah lebih baik kenyataannya Biksu Buddha hanya sibuk mengurusi ritual kematian saja, meminta sumbangan untuk renovasi dan membangun kuil baru. Hampir tidak peduli umatnya yang berjiwa korup dan moral masyarakat yang semakin merosot. Kedua, ajaran moral yang bersumber pada ajaran konfusius yang cukup banyak pengikutnya, hanya berisi larangan-larangan saja, minim anjuran yang positif. Selain itu ajaran konfusius tidak ada ajaran kesetaraan. Para pejabat diberi banyak hak namun tanpa dibebani kewajiban. Sedangkan rakyat jelata diberi banyak beban kewajiban tetapi tidak diberi hak. Ajaran para filosof hanya bersifat teori saja. Sehingga tidak banyak membawa perubahan. Ketiga, sanksi hukum yang diterapkan di Jepang memang bisa membawa efek jera, membuat orang takut berbuat jahat, tapi tidak proaktif membawa orang berbuat baik. Orang dapat saja berbuat baik di depan publik atau hukum, namun dapat berbuat jahat jika tidak ada orang lain yang mengetahui. Artinya perbuatan baik dilakukan karena alasanalasan tertentu, tidak karena kesadaran dan kewajiban. Selain itu hukum dibuat oleh para penguasa yang notabene adalah kelompok minoritas. Hukum yang dibuat kelompok minoritas belum tentu cocok dengan kelompok mayoritas yaitu rakyat kebanyakan. Untuk itu perlu ada perubahan tatanan, nilai-nilai kemasyarakatan secara mendasar. Dohi Masataka menjelaskan, langkah-langkah yang harus ditempuh adalah 
a. Dibentuk perwakilan asosiasi-asosiasi perubahan pola hidup Jepang di daerahdaerah seluruh wilayah Jepang. Tugas utamanya untuk membentuk opini publik bahwa kebiasaan dan kehidupan yang terjadi di masyarakat perlu ada perbaikan. Adat-adat istiadat yang menghambat kemajuan hendaknya ditinggalkan secara bertahap untuk menuju perubahan yang lebih baik.

b. Perlunya dibentuk opini dan penyadaran masyarakat mengenai pentingnya reformasi adat sangat dibutuhkan untuk membangun Jepang. Cara yang paling efektif dilakukan adalah para pengurus Dewan Pimpinan Pusat. Mereka turun ke daerah-daerah bekerjasama dengan Dewan Pimpinan Cabang untuk berceramah tentang langkah-langkah refomasi adat. Pada kesempatan ini sekaligus menjaring masukan-masukan dari masyarakat tentang masalahmasalah yang dihadapi. Kemudian didiskusikan untuk mencari metode reformasi yang tepat pada setiap daerah dan dicarikan solusinya. Agar perubahan tetap terarah dan tidak menimbulkan gejolak di masyarakat. Langkah-langkah reformasi setiap tahun perlu dilakukan evaluasi oleh Dewan Pimpinan Pusat untuk melihat tingkat keberhasilannya. Demikian seterusnya hingga tujuan reformasi tercapai. Masataka menyadari perubahan semacam ini butuh waktu lama. Porgram ini diadopsi pemerintah Jepang dengan isitilah berbeda. Local Improvement Movement adalah program Kementrian Dalam Negeri Jepang tahun 1909. Program ini dijalankan secara konsisten di Jepang hingga tahun 1970 an. Memang proses itu berlangsung cukup lama sehingga membentuk bangsa Jepang seperti saat ini. Karakter bangsa Jepang dikenal dengan sifatnya yang rajin, disiplin, teliti, hemat, jujur dan tanggung jawab.

Berdasarkan tahapan strategi kebudayaan, Bangsa Jepang dapat menarik diri secara ontologis dan melakukan refleksi. Bangsa Jepang mampu memahami dan menganalisa diri sendiri sehingga berhasil merumuskan kekurangan-kekurangan dan mencari jalan keluarnya. Caranya adalah belajar dari bangsa barat. Misalanya mempelajari budaya disiplin dan kerja keras ala barat dan menerapkannya untuk dirinya sendiri. Tradisdi yang mereka anut sesuai ajaran moral turun-temurun mulai dibongkar diganti kebiasaan-kebiasaan yang positif dan praktis, hasilnya nyata dan terukur. Agama-agama yang mereka anut mulai dipertanyakan fungsinya. Tahap ketiga dalam strategi kebudayaan terlihat pada Bangsa Jepang yang senantiasa mencari keterkaitan atau relasi-relasi dengan lingkungan.

Persoalan mendasar terletak pada tataran perkembangan budaya yang akan membawa konsekuensi logis pada perubahan kehidupan. Kejujuran dalam perkembangan budaya merupakan sesuatu yang imperatif untuk mencapai kehidupan yang lebih bermartabat. Sikap model ini yang dapat membawa perubahan besar pada Bangsa Jepang. Reformasi budaya pada giilirannya membawa perubahan pada dunia politik. Nampak jelas budaya memiliki peran yang penting dalam membentuk dan merubah pola perilaku dari suatu bangsa, perbaikan dan kemajuan bisa terjadi apabila terjadi perubahan budaya ke arah yang labih baik secara konsisten (Jaharuddin, 2015).

Bagaimana dengan reformasi di Indonesia? Tentunya reformasi budaya bisa menjadi dasar perubahan kehidupan yang lebih baik, sekalipun reformaasi politik lebih cepat dilakukan. Namun reformasi politik memerlukan kejujuran dan konsistensi dalam pelaksanaannya.

\section{SIMPULAN}

Konsistensi dan kontinyuitas menjadi kata kunci keberhasilan Bangsa Jepang. Masyarakat Jepang berhasil merefleksikan dirinya. Merumuskan kekurangan-kekurangan dan langkah- 
langkah perbaikan secara konsisten dan kontinyu.

Bangsa Jepang berhasil menentukan skala prioritas dalam memperbaiki nasib bangsanya. Perbaikan memerlukan jangka waktu yang panjang dengan rumusan yang jelas dan jujur. Proses ratusan mampu mengubah karakter Bangsa Jepang untuk mencapai kejayaannya.

\section{DAFTAR PUSTAKA}

Sumber buku dan Majalah:

Ong, Susy, 2017, Seikatsu Kaizen: Reformasi Pola hidup Jepang: Panduan Menjadi Masyarakat Unggul dan Modern, Gramedia, Jakarta.

Peuersen, Van, 1976, Strategi Kebudayaan, Kanisius, Yogyakarta.

Sugono, Dendy dkk., 2008, Kamus Besar Bahasa Indonesia, Departemen Pendidikan Nasional, Edisi keempat, Gramedia, Jakarta.

Sutrisno, Slamet, 1994, Kebudayaan, Peradaban, dan Pendidikan, dalam jurnal Filsafat Seri 19 Agustus 1994, hal. 41.

Sumber internet:

Jaharuddin, 2015, Reformasi Budaya, https://www.kompasiana.com/jahar uddin/reformasi-

budaya_551744e18133115f669de4 45 diunduh pada tanggal 8 Juni 2018.

http://kbbi.co.id/arti-kata/budaya, diunduh pada tanggal 8 juni 2018 . 